\title{
Neoliberalizing food safety and the 2008 Canadian listeriosis outbreak
}

\author{
Ken Hatt • Kierstin Hatt
}

Accepted: 3 February 2011/Published online: 2 April 2011

(C) Springer Science+Business Media B.V. 2011

\begin{abstract}
This paper examines evidence regarding neoliberalization of the social organization of Canadian food safety from a series of documents produced in response to the Canadian listeriosis outbreak in 2008. The outbreak is described, then interpreted within a neoliberal context, where: (1) neoliberalism operates as an ideology (2) that enables a socio-political and economic strategy within (3) a project pursued by coalitions seeking to consolidate power through (4) a process of neoliberalization. Following Gramsci's work on power, it is argued that food safety serves as an attractor, organizing consent within a neoliberal context. Testimony before a parliamentary subcommittee, official reviews, an independent investigation, food inspection records, and media reports have been examined to identify the key factors associated with the outbreak and the process of neoliberalization. The events associated with the outbreak are described first, as activities and practices in organizational settings (governance, sanitation, and production), and secondly, as components in a food production network where consent is organized around food safety.
\end{abstract}

Keywords Neoliberalization - Food safety - Listeriosis · Food governance $\cdot$ Risk management

\footnotetext{
K. Hatt $(\square)$

Department of Sociology, University of Victoria, Victoria, BC, Canada

e-mail: kenhatt@uvic.ca

K. Hatt

Department of Sociology, University of Alberta, Augustana Campus, Camrose, AB, Canada

e-mail: hattk@Augustana.ab.ca
}

\author{
Abbreviations \\ AAFC Agriculture and Agri-Foods Canada \\ CAC Codex Alimentarius Commission \\ CFIA Canadian Food Inspection Agency \\ CVS Compliance Verification System \\ FSEP Food Safety Enhancement Program \\ HACCP Hazard Analysis Critical Control Points \\ HC Health Canada \\ PHAC Public Health Agency of Canada \\ RTE Ready-to-eat \\ WTO World Trade Organization
}

\section{Introduction}

This paper examines a Canadian listeriosis outbreak in 2008 that led to 23 deaths. Events associated with the outbreak are described and linked to a neoliberal context through an application of a neo-Gramscian understanding of power. Using that approach, food safety is viewed as a discursive formulation that serves to organize and manage consent regarding programs and practices in a variety of organizations in the Canadian food network. But competing organizational priorities and deficiencies in implementing risk management strategies have made the neoliberalization of food safety a turbulent matter. Responses to the listeriosis outbreak at a Maple Leaf Foods plant in Toronto provided an opportunity to examine the neoliberalization process. They included reviews by federal and provincial food safety organizations, parliamentary subcommittee hearings, an independent investigation, and numerous statements in the media. This case study does not explicate the actual social realities of those involved in the system or of those who must deal with it. Nor does it 
examine the political economy of ready-to-eat (RTE) foods. It does, however, situate the key factors leading to the outbreak in a broader context than the more focused political and policy approaches of other accounts. The social relations are examined, first, as activities and practices in organizational settings, and secondly, as connected components in a food production network. We begin by describing the outbreak, then the neoliberal context, how food safety is organized in relation to that context, activities in the key organizational settings (governance, sanitation, and production) associated with the outbreak, and we conclude with a discussion of the problematic process of neoliberalizing food safety.

\section{The Canadian listeriosis outbreak}

In mid-July of 2008 Toronto public health officials began to link listeriosis infection of two residents at the same nursing home with a rise in cases reported throughout the province of Ontario. Listeriosis is a food borne illness most often contracted by ingesting food contaminated with the pathogenic bacteria, Listeria monocytogenes (hereafter, Listeria) (Farber et al. 2007). Listeria is capable of growth and reproduction in cold temperatures (Bortolussi 2008) and able to survive exposure to sanitizing solutions. It can grow well under either aerobic or anaerobic conditions, as in foods packaged under vacuum or modified atmospheres (Lado and Yousef 2007). Listeria readily colonizes by forming a protective biofilm that facilitates resistance to sanitation. Incomplete sanitation procedures may induce a further stress-adaptive response that leads to what is referred to as a viable, but not culturable state (Sardessai 2005). In this condition it is not culturable, negating the "Gold Standard" of detection based on identification of cultures (Heim et al. 2002). Recent research indicates that it may also adapt its shape, having lost its cell walls, with the result that the normal immune system macrophages (white blood cells) may not recognize it as a pathogen (Bortolussi 2008; Dell'Era et al. 2009). Specific segments of the population, known as the "YOPI" (young, old, pregnant or immuno-compromised) are especially vulnerable (Szabo et al. 2008).

Meat samples from the nursing home were sent to federal laboratories for testing as provincial public health units began reporting more than double the usual number of cases. By 4 August the initial test results returned, showing higher than usual positive results. The Canadian Food Inspection Agency (CFIA) began a food safety investigation and about a week later, samples from several provinces were matched to the same source. Maple Leaf Foods - a pre-eminent Canadian producer of RTE meatswas identified as the probable source, and it advised distributors to begin holding some products as a precaution. Further tests confirmed that the Listeria had definitely come from the Maple Leaf Foods products. On 17 August the company began a recall that eventually extended to over 200 products. Three days later the Maple Leaf Foods processing plant in Toronto was shut down for sanitization. It was re-opened on 18 September after extensive disinfection and sanitization. On 20 October the CFIA announced that one production line was still testing positive and would not be permitted to operate, but that other production lines would be opened for distribution. The outbreak was declared over on 8 December 2008. In the end, 57 persons were identified as having been infected with Listeria, of whom 23 died. Nearly all of the victims were older persons who had eaten deli-meats in hospitals, nursing homes or senior residences.

Public reactions to the outbreak represented the variety of views around food safety networks. In general, there were three points of view. The first was that since the problem was found, the inspection system was working, as it should. This view was expressed by the two Ministers responsible for health and agriculture, within whose joint mandate the matter fell (Globe and Mail 2008; Canadian Press 2008). Another view was that inadequate maintenance and sanitation practices led to the outbreak. One newspaper reported a long-time Bartor Road plant employee, wanting to remain anonymous, as saying, "They haven't cleaned some of the machines' (interiors) in 4, 5 years" (Anonymous 2008). An unnamed food inspector added: "We do not have the same presence we used to have in the processing facilities. When the cat is away, the mice will play" (Schmidt 2008). Dr. Dubey, Toronto's associate medical officer of health, said: "I've never seen anything like this. The fact that so many came back positive shows how contaminated the source was. ... There had to be a reservoir of the bacteria growing" (Cribb 2008a).

A third point of view held that the outbreak occurred because the inspection system was not adequate or not being well implemented. The reasons ranged from inadequate financial support to skepticism about the efficacy of an audit-based system. The Inspectors' union pointed to both the inadequacy of support and a system that relies primarily on auditing company-based reports. Food microbiologists pointed to the absence of a comprehensive information, inspection and analysis system in Canada. Others suggested a conflict of interest within the CFIA. Chris Mackie, an associate medical officer in Hamilton, Ontario, said, “... the real issue is that public-health goals, objectives, and activities should be conducted independently of political or economic goals. Keeping our markets open is an important objective. But it shouldn't be the objective of an agency that has food sanitation as its goal" (quoted in Howlett and Alphonso 2008). 
Prime Minister Stephen Harper announced an independent investigation (rather than a more stringent formal inquiry) on 3 September 2008 (Chase et al. 2008). An Independent Investigator was appointed and began work in late January 2009. In early February, Health Canada tabled its review of the outbreak with a report titled "Lessons Learned" (Health Canada 2009). About the same time the Standing Committee on Agriculture and Agri-Food of the House of Commons created a subcommittee on Food Safety. That subcommittee began hearings in late March, meeting on 13 occasions until mid-June. By mid-April four reports were issued simultaneously by the Chief Medical Officer of Health of Ontario (Chief Medical Officer of Health 2009), the CFIA (CFIA 2009a, b), and the Public Health Agency of Canada (PHAC 2009). The parliamentary subcommittee on Food Safety (Subcommittee on Food Safety 2009) and the Independent Investigator (Independent Investigator 2009) reported by the end of July. After a quiet summer on the listeriosis front, in November the federal government appointed a top bureaucrat at Agriculture Canada to lead an "overhaul" of food safety organization (Schmidt 2009).

The tragic occurrence challenged the political legitimacy of food safety management, but it did not develop into a major crisis. The main outcome was organizational scrutiny, with some reorganization of roles, objectives in the agri-food management complex. The material from reports, studies, and investigations, noted above, provided valuable material on the neoliberalization of food safety organization. In addition, we have analyzed the complete reports of the Subcommittee on Food Safety, the transcripts of testimony before the Subcommittee (House of Commons Committees 2009), the report by the Independent Investigator, 142 media reports (from August 2008 to August 2009), 170 Inspection Reports from the Bartor Road plant (CFIA 2009c), Maple Leaf Foods corporate documents and scholarly literature relating to listeriosis. They provide, we believe, a fairly comprehensive view of the organization of social relations in food safety as they relate to the listeriosis outbreak.

Juska et al. (2003) provide a context for the present work in their examination of evidence and causal theories that attempted to account for outbreaks of $E$. coli O157:H7 in the US from 1982 to 2000. A central conundrum they addressed was that there appeared to be lower levels of meat contamination, yet greater potential for outbreaks due to the industrial scale of activity and the inability of beef producers to introduce changes in order to reduce pathogens. They reviewed and classified approaches that emphasized variously individualistic, institutionalist, and agro-industrial ecological explanations and found each of these inadequate to resolve the problem. They propose that the agro-industrial ecology approach be used, along with political economy and risk theory to more successfully address the problem. The present paper takes an approach that has similarities to the one proposed by Juska et al. (2003), however, there are some important differences. This paper focuses on describing one outbreak rather than an entire set of incidents. It is, instead, a case study that follows the outbreak and the reactions to it in a range of sources that are noted above. Finally, it does not attempt to present a causal analysis, proposing a more eclectic approach that relates critical factors to the changing assemblage of power associated with food safety.

\section{The neoliberal context}

We begin from the premise that neoliberalism in Canadaas in many OECD countries-serves as a context within which the listeriosis outbreak can be examined. Neoliberalism has taken on a variety of meanings in part, because, as Harvey (2005) has observed, it has become a central organizing feature of contemporary affairs. We suggest there are at least four aspects in the neoliberal context, where: (1) neoliberalism operates as an ideology (2) that enables a socio-political and economic strategy, within (3) a project pursued by coalitions seeking to consolidate power through (4) a process of neoliberalization. This understanding guides the following discussion.

Laxer (1995) and Jessop (2002) argue that neoliberalism, which emerged from liberalism, rests on the assertion that the pursuit of self-interest by individuals is the most important human characteristic and the basis for promoting the common good. Following from this premise were corollaries that a free market and the exchange of goods (or ideas) are the source of innovation, efficiency, and the development of personal and social well-being. Liberalism has been associated with the Keynesian welfare national state (KWNS) that emerged in the early to mid-20th century (Jessop 2002). Following Polanyi (1944), Jessop points out an inherent contradiction: that a market economy always rests upon and is sustained by the social institutions and practices within a social formation. Jessop also contrasts liberal with neoliberal social formations, suggesting that the former are more focused on activities at the national level, whereas the latter explicitly stress international competitiveness and policies to enhance those markets. As these are developed, social policies become secondary, labor markets more flexible, and welfare projects become programs to turn people toward entrepreneurialism and work. The role of the central government is diminished through downsizing or shifting programs to organizations and groups outside the state, often through the creation of partnerships. 
Peck and Tickell (2002), however, argue that neoliberalism is not monolithic, but a discursive process, which they refer to as neoliberalization. They trace the history of neoliberalization, from "rolling back" regulation in the early years to "rolling out" through programs that provided assistance and created a new infrastructure involving partnerships with non-governmental organizations. Strategies of technocratic risk management assume prominence in many of these programs, and some will be discussed shortly. The result has been that many organizations created in the liberal era have been superseded or neoliberalized. Nevertheless, some remnants of the KWNS remain, in disjunction, serving to limit these new strategies and, sometimes, even providing slim shelter for alternative activity. Guthman $(2006,2007,2008)$ describes the process of neoliberalization, showing how neoliberal governmentality can transform and absorb subjects into a system that emphasizes consumption. Pechlaner and Otero (2010) expand upon these notions in their discussion of the emergence of a neoliberal food regime, where they propose that the process of neoliberalization can be understood as "neoregulation."

Antonio Gramsci's (1971) work on power is useful here, both to inform our understanding of the neoliberal project and to link the features of neoliberalism with our case study. Gramsci recounted how, in the early Twentieth century, capitalist forces gained or maintained their ascendancy, in part, by an ability to organize the consent of the bulk of the population in a society. He referred to this as "hegemony," where a historical bloc of interests were able to gain power and prevail, in part, by constructing an intellectual and moral unity (through ideological formulations) that could dominate the agenda in which political struggles were waged (Gramsci 1971). Hegemonic projects usually involve a coalition of transnational corporations, a political party, and/or specific interest groups whose coming together makes it possible to achieve some, if not all, of their objectives. Such a hegemonic arrangement tends to revolve around appropriation of a political arena and claims to legitimacy. Examples of recent ideological formulations that lend legitimacy to hegemonic projects include the now-familiar campaigns organized around such terms as "budget deficit" or "terrorism." These endeavors can include coercive as well as discursive techniques so as to organize the concerns of the populace into a form of "spontaneous" consent. As Gramsci put it, these formulations would have the effect of making a universalized claim on political activities in a social formation. Ideological formulations help create and maintain an agenda for action, especially when used in a discourse that provides a frame for mobilizing support and limiting resistance. In sum, Gramsci's view could be simplistically described as follows: ahegemonic arrangement $=$ historical bloc

$$
+[\text { coercion }+ \text { consent }(\text { attractor })] \text {. }
$$

We prefer the term "attractor" to designate these universalized ideological formulations. This is primarily because the term "universal" implies only one ideological formulation, whereas in contemporary social formations there are many such discursive devices enlisted in hegemonic projects. We extend Gramsci's view that consent can be organized around an ideological formulation to propose that a variety of such formulations serve as attractors, organizing consent around neoliberal projects through discursive practices which rely on notions of missions, visions, and agendas. For example, the term, neoliberal, serves a central a purpose in organizing consent in a number of social formations (hence, Harvey's [2005] statement that neoliberalism can be seen as ideology, strategy, project or process). Likewise, it appears plausible to suggest that food safety may serve a similar role in organizing consent around the production, distribution, and consumption of food. That is, food safety brings together a variety of actors and organizations by providing an agenda that can organize consent and serve to focus contestation regarding goals, legislation, regulations and practices.

Hegemonic projects and attractors cannot, however, be taken as given or in any sense permanent. These arrangements are contingent, highly contested, and require continuous effort at achieving consent (Carroll 1990). At their best, they are a tentative achievement, co-existing with deficiencies, competing objectives, and other obstacles that limit consent. Furthermore, the processes of organizing consent may also create opportunities for counterproductive activity, resistance or constructing counter-hegemonic movements (Carroll 1990).

We work, then, from the assumption that neoliberalism serves as an organizing feature of contemporary society (Harvey 2005) and that the strategies of neoliberalization associated with organizing and managing consent provide a linkage through which we can examine the potential societal crisis presented by the listeriosis outbreak. In this situation, the food production network clearly revolves around marketing products that, in turn, require consumer confidence. So the key question becomes: to what extent does food safety serve as an attractor through which this activity is organized? This involves documenting the extent to which food safety does and does not serve as an attractor. Finally, it should be made clear that this study is not attempting to trace the sources of food regimes or establish the validity of food regimes as macro-sociological theoretical concept. Neoliberalization is only used here to help describe what Guthman (2006) refers to as an "actually existing neoliberalism." Following Pechlaner and 
Otero (2010, p. 204) we examine the listeriosis outbreak and neoliberalization in the Canadian nation-state to understand "... how and whether their internal sociopolitical dynamics may become independent factors that could alter dominant trends in the world economy from the bottom up."

\section{Neoliberalization and the organization of food safety}

Neoliberalization has led to a more condensed and decentralized state that, in turn, has transformed the organization of food safety. This administrative re-organization reflects trends in corporations as seen in the shift from closed to open systems models in organizational theory and strategies of management (Buckley 1967; Orton and Weick 1990). In the broadest sense, the re-organization of the state around "open systems" led to a bifurcation that involved, on the one hand, international strategies sensitive to transnational corporate agendas while, on the other, developing administrative techniques for societal management. Domestically, the process affected organizations where decision-making was concentrated, operations were decentralized and integration was accomplished through budgetary and cybernetic coordination (Hymer 1971). This paradigm contributed to the development of strategies for the risk management and organization of food safety. These trends are reflected in recent analytical approaches to the production, distribution, and consumption of food, which have been characterized variously as commodity chain (Gereffi and Korzeniewicz 1994; Talbot 2002), value chain (Gereffi et al. 2005; Gibbon et al. 2008), production network (Coe et al. 2004; Hess 2008) and a circuit (Hudson 2004; Pritchard and Fagan 1999). In this case study, the food system will first be described as a network organized around three interrelated areas of activity: food governance, food sanitation, and food production. Since these activities are part of a network in which production, distribution, and consumption are interconnected, the second description will deal with the way in which food safety serves as an attractor that links those practices with the neoliberal context.

The focal point in the governance of food safety is on standards, and following Busch (2004), Hatanaka and Busch (2008), Mutersbaugh (2005), and Stewart et al. (2002), we define them as norms that imply a set of reciprocal rights and obligations with regard to a relationship or a practice. Standards have come to be of direct interest to transnationals that have generally pressed political authorities for trade liberalization. They also reflect the impact of corporate-based scientific research, which has expanded through sponsored research programs. Other international actors include multilateral institutions and agro-food network NGO's such as the International Federation of Organic Agriculture Movements (IFOAM) (Mutersbaugh 2005). The World Trade Organization (WTO) is the most prominent multilateral institution, acting as an arena for the promotion of trade liberalization. Standards have been developed at many levels of organization, but the most well known come from the Codex Alimentarius Commission (CAC). For example, such activity is described in an article by Post (2005), who traces the history of the approval of the General Standard for Food Additives (GFSA) at the CAC. Neoliberalized food standards are not strictly scientific, but are usually referred to as "based on science." They combine science and policy, two essentially different types of enterprise (Millstone 2007; Millstone et al. 1999). Millstone and others argue that there is a general denial of the incompatibility between science and policy decision-making that has not been adequately addressed. Along with Busch (2001), they express reservations and concerns about scientists, risk assessors, and risk managers being able to translate risk management into a practice that reflects the openness and democratic considerations implied in the notions of liberal democracy.

One way to manage that difficulty is through the creation of boards that act as clearinghouses and coordinate standards development within a country. Each nation or jurisdiction has its own particular array. In Canada, for example, the Standards Council of Canada oversees the construction of a National Standards System, which is linked to the Canadian General Standards Board. Various agricultural boards and agencies are loosely coupled within a complex that orchestrates the management of agricultural activities. These boards also interface with political authorities and accrediting and certifying bodies. The strategy is based on risk management, where assessments and evaluations of risk are translated into technologically achievable objectives for levels of acceptable risk that guide standardized procedures. Certification bodies link the standards to organizations involved in agricultural production. Put another way, the task here is one of harmonization of competing standards with political, economic, and ecological forces.

Standards also reflect the activities of those involved in production, distribution, and consumption of food. These are a diverse set of interests, but they share the characteristic of dealing with the regulatory enterprises that have jurisdiction over these matters. Producers range from being organized around local to globalized networks. Large-scale organizations and the agencies designed to manage them tend toward countervailing organizational forms (Galbraith 1952). These larger, loosely coupled organizations can absorb the cost of programs for monitoring safety much more readily than smaller operations. In fact, risk 
management may actually increase the advantage of larger operators and shape the market to their advantage. This is also the case for consumers' organizations, although the consumer voice is usually located at the rear of the standards production process and is reliant on labeling that tends to reflect legitimized standards. Consumers can find voice, however, at the point of purchase and, on occasion, in response to disasters. Finally, various political authorities are involved in food governance, as will be noted below. Political authorities do have input into the multilateral internationals, but it is a lagged influence, since they usually work from previous agreements. This tends to limit effective political action to tactics of evasion or negotiating future standards.

In sum, food safety is organized around a wide array of bodies and networks whose activity is orchestrated through the creation and administration of standards. At the international level, both transnational corporations and international institutions (such as the WTO, through agreements regarding Sanitary and Phyto-Sanitary products, and the International Federation of Organic Agriculture Movements) combine the essentially incompatible tasks of establishing generalizations about risk with acceptable levels of risk in food products. These organizations are intensively and competitively involved in the legitimization of standards on accreditation and certification regarding food safety. The WTO serves as the major international arena for the promotion of trade liberalization and the most prominent standards regarding food safety have come from the CAC. Political authorities coordinate activities within their jurisdictions by generating formats for exemption and application through strategies based on risk management. Food governance, sanitation, and production are undertaken within this neoliberalized context.

\section{Food governance}

With regard to Canadian governance, agriculture and food safety are shared jurisdictionally between the federal, provincial, and local authorities. This creates a number of discrepancies and contradictions within and between jurisdictions. At the federal level, food governance in Canada is a shared responsibility between Agriculture and Agri-Foods Canada (AAFC) and Health Canada (HC). HC is responsible for formulating safety standards relative to both the safety and nutritional quality of food. This can be seen in the Listeria policy developed by Health Canada. In accord with Canada's "Integrated Risk Management Framework" (Treasury Board 2001), it serves as a comprehensive strategy for managing relationships between a governmental department and its operating environment. At this level, risk management (Stewart et al. 2002) revolves around identifying problems associated with food hazards through assessments of risks relying upon scientific criteria and options for protection that are technologically feasible and cost effective. These then become a basis for identifying options that correspond to food safety objectives that are to be achieved through "Good Hygiene Practices." These, in turn, are implemented through the CFIA. They are designed to reflect trade and commercial inspection requirements for foods destined for export or shipment between provinces in concert with the AAFC. While Health Canada assesses the effectiveness of the CFIA, the CFIA reports to Agriculture and Agri-Foods Canada. In fact, the report by the Independent Investigator was submitted to AAFC rather than HC. The Public Health Agency of Canada (PHAC), operating under the Chief Public Health Officer of Canada, has the mission of anticipating and responding to public health emergencies in coordination with $\mathrm{HC}$. While general health surveillance is conducted by HC, surveillance of illnesses and diseases is delegated to the PHAC.

Because the listeriosis outbreak began in the province of Ontario, the Public Health Division in the provincial Ministry of Health took the lead in doing the investigation and in managing it, following constitutional and jurisdictional arrangements. After a SARS (severe acute respiratory syndrome) outbreak in 2005, the Ontario Ministry of Health had established a web-based information system for public health surveillance that was accessible to federal agencies. Ontario defines listeriosis as a reportable disease (not done federally), so knowledge of listeriosis cases became available as soon as the local health units entered the data. However, since listeriosis testing has been centralized in Canada, samples must be sent to the federal laboratories jointly operated by HC and PHAC, which are able to perform testing based on molecular typing. David McKeown, the Toronto Public Health Medical Officer, acted on the basis of epidemiological evidence, thus leading him to a much earlier (if perhaps less reliable) decision than if he were to wait for the results from molecular typing employed by the federal laboratories. The question of the trade-off between prompt decisionmaking and seriousness of the outbreak arose at the subcommittee hearings. Federal authorities insisted that a decision must rest on the more sophisticated techniques, to which McKeown replied that in serious cases of this type, relying on the principle of "substantial evidence" (favored in Canada and the US) rather than the "precautionary principle" (favored by the EU) represented a decision to err in favor of industry protection rather than public health (House of Commons Committees, 27 May 2009, line 1615). 


\section{Food sanitation}

The advent of risk management strategies in food safety has brought pressure for standardization between the various jurisdictions that are involved. This is especially the case for producers and processors who wish to export meat products across provincial boundaries or outside Canada, because they must meet federal requirements. It is within this context that food sanitation can be described. Food safety policies developed at $\mathrm{HC}$ are implemented by the CFIA in its Food Safety Enhancement Program (FSEP), which is applicable to most food. In this program the CFIA relies on two major instruments: the Hazard Analysis Critical Control Points (HACCP) strategy and an inspection plan known as the Compliance Verification System (CVS). The CFIA has increasingly employed HACCP as method for assuring safety at specific points in production or processing rather than the traditional method of inspecting through product testing. In order for a plant to meet the requirements for federal registration, it must use HACCP-based food sanitation procedures.

The HACCP system is a risk management technique for applying science-based principles to food production. This is a joint responsibility whereby firms design and implement their own HACCP safety programs and keep records while the CFIA defines basic requirements, approves the plan, and verifies their operation through the CVS inspection system (Anonymous 2007). The program minimizes risks by identifying hazards, determining critical points and limits for activity. It sets out procedures to monitor, correct, verify and document practices that apply to premises, transportation, receiving and storage, equipment, personnel, sanitation, pest control, and recalls of contaminated products (Anonymous 2007, pp. 10-28). The approval process begins with a plan prepared by a firm, which is then approved by the CFIA. The steps revolve around identifying critical control points and monitoring through recordkeeping (Anonymous 2007, pp. 95-112). The organizational culture of inspection developed around sensory examination and there is still need for observation-based evidence. The major emphasis, though, has increasingly been based on audits whereby establishments keep records of their HACCP practices and samples of records are then inspected by the CFIA. Two other tests are available. Microbiological inspections of end products (Sampling plan M200) and environmental and food contact surfaces (Sampling plan M205) were both intended to be conducted from three to six times a year in an establishment. However, in 2005 the CFIA eliminated the obligation of inspectors to conduct environmental monitoring for Listeria on food contact surfaces (Independent Investigator 2009, p. 42).

Once a HACCP plan for an establishment is in place, it is audited through the CVS. The audit is intended to verify whether establishments are complying with requirements as established in their HACCP plan. Audits of inspection records are based on a sampling design that varies in relation to the number of critical control points in its operation and the risk of its products. In smaller operations, records from two points are randomly chosen for inspection. In the largest operations, up to 13 audits of records will be randomly examined. The level of risk in the product also determines frequency of auditing, where audits range from once a quarter for high-risk operations (e.g., pasteurization, cooking or drying RTE meat, grinding or slaughtering) to once a year for low-risk operations (that deal with honey, fruits or vegetables processed by heating, freezing, or drying). These two instruments are used to assure that the actual practices of food processors conform to food safety standards.

\section{(Unsafe) food production}

The contaminated meat at the Bartor Road plant (97B) was the result of a combination of corporate production and safety procedures and CFIA inspection practices that were applied to a new product. With regard to the first, in 2008 the CEO of Maple Leaf Foods promoted a corporate agenda of "belt-tightening" due to unpredictable markets and price inflation (Cribb 2008b). In addition, the plant had gaps and lapses in sanitation procedures. We obtained copies of CFIA inspection reports from January 2007 until April 2008 that had been acquired through the Freedom of Information Act and made available online by the Canadian Broadcasting Corporation (CFIA 2009c). Our analysis of those records showed that, despite the CFIA assertion that around $90 \%$ of the inspections in early 2008 were acceptable, evidence indicated a less than rigorous sanitary regime at the plant. We examined all the reports with their descriptions of physical environment and sanitation problems. They provided evidence of recurring water leaks and condensation as well as temperatures in refrigeration units that exceeded the minimum standard. For example, an inspection report on water leakage dated 1 May 2007, stated: "This is a recurring observation as documented in observations 15 February 2007 and 27 February 2007." We confirmed the accuracy of that statement from those earlier reports. A second example was found in an inspection report of 7 July 2007, which states: "This issue (refrigeration unit heavily leaking water) was reported to Management on each of the last 3 consecutive visits." Third, an entry on 29 November 2007 (CFIA 2009c), reported that the ladies washroom/change room had two toilets out of order, with foundation exposed, water leaking through foundation. It was later noted that this was corrected over 5 months later on 16 May 2008. Between 9 January and 9 
November 2007, six entries were made about temperatures in the refrigeration units exceeding the minimum standard. In addition, sanitation concerns were found in 22 entries such as: "visible contamination on ceiling floors and walls" (CFIA 2009c: 13 March 2008). On 5 October 2007 an inspector wrote: "I discussed with xxx the need to improve the regular sanitation of the perimeter areas of the Kitchen and Smokehouse. We were on site to look at a buildup on the floor and sink area between the smokehouse and the potwash, and on the walls and equipment between the smokehouses. $\mathrm{xxx}$ acknowledged the issue and stated that he would advise the Sanitation supervisor of the concern" (CFIA 2009c: 5 October 2007). These examples suggest deficiencies that were not just exceptional but were recurring.

Turning from food processing practices to the CFIA inspection, as noted above, the new audit-based regime, the CVS, was being introduced, supplanting the more traditional method of physical inspection. In addition, the requirement for microbiological inspection of food contact surfaces had been dropped in 2005, which led to a "communication gap." Because the inspectors were focused on audit-based sampling of records, they did not know of or inquire about patterns of positive results that had been discovered and "corrected" by plant employees. This contributed to a failure to identify the pattern of positive tests for the presence of listeria in the plants (Independent Investigator 2009, pp. 33-37). A second problem involved resources and staff to undertake inspections. The Independent Investigator stated: “... of the two inspectors assigned to the Bartor Road plant, the day shift inspector had to cover seven different plants and their workloads left them limited time to accomplish their tasks in depth" (Independent Investigator 2009, p. 37). This may have been associated with a third difficulty, the failure to undertake audits. The Independent Investigator stated that audits “... did not take place at the Bartor Road plant at the prescribed frequency in 2005, 2006, 2007. No audits were conducted in 2008 and only three audits over the period 2005-2008" (Independent Investigator 2009, p. 36). This is in contrast with the CFIA report which states that “...during the pilot period in 2006-2007 inspection staff conducted food safety reviews (FSEP audits) and CVS inspection and sampling tasks ..." (CFIA 2009b, p. 6).

Finally, a third major contributing factor was the introduction of a new product. In 2008, Maple Leaf Foods was approached by a distributor to develop low-sodium deli meat that was to be served in hospitals and long-term care facilities. Maple Leaf Foods created a recipe with less sodium and the market for this product expanded greatly in a very short time. This led to a rapid increase in production. The Independent Investigator was told that the market for this product increased from 20 cases a week to $2,000-3,000$ cases a week (Independent Investigator 2009, p. 34). The Independent Investigator also noted "reduced sodium levels in deli meats are known to increase the risk for bacteria growth, including Listeria" (Independent Investigator 2009 , p. 32). Because of heavy demand, the plant began operating on double shifts. The only time for sanitation and inspection was between the midnight and morning shifts, requiring additional funds for inspection in "overtime" periods. Complete cleaning took place only on weekends and pieces of equipment were not dismantled. All parties agreed that the outbreak could be traced to several machines in the plant, commonly known as the slicers. In such a situation, the communication "gap" noted above assumed greater importance. It seems plausible that this combination of failures and actions led to the listeriosis outbreak.

\section{Food safety as an attractor}

Food safety served as an attractor that provided a neoliberal agenda for the production, sanitation, and governance of food in the Canadian listeriosis outbreak in 2008. Although it served to organize consent, it was not sufficient to prevent the contamination, nor was it adequate to provide a consensus on food safety around the food production net.

Immediately after the outbreak, corporate, political, and bureaucratic leaders framed the issue in assurances of food safety. The ministers of Agriculture and Health, who shared jurisdiction, minimized their responsibility, asserting that since the problem had been found (albeit by a provincial health operation), the system was working. The Prime Minister took a softer tack, offering his condolences, adding that the outbreak demonstrated why his governmental project to revamp the food inspection was needed (Canadian Press 2008). The federal government served as a site for tracking efforts to deal with events and as an arena of political management through bureaucratic reviews, parliamentary hearings and an independent investigation. The parliamentary hearings heard witnesses from about 20 government agencies and 50 corporate, private sector, and advocacy organizations. Space does not permit extensive documentation, but testimony and discussion confirmed that most supported a neoliberal vision of food safety: a nationally integrated and science-based set of risk management inspection strategies harmonized with international trade standards.

Michael McCain, the CEO of Maple Leaf Foods, figured prominently in the media by shouldering responsibility for the outbreak, assuring the public of renewed sanitation efforts by his firm and articulating a neoliberal interpretation of the events. Expressing remorse, he also pointed out that Listeria was pervasive and that eliminating or 
eradicating it from the food industry was an "impossible expectation." Nevertheless, McCain stressed several times that his company's safety practices exceeded inspection requirements (House of Commons Committees, 20 April 2009, line 1610), and that "The food in Canada is safer than it has ever been in the history of mankind. Why? Because the industry is committed to improving every year. ...we have an industry in Canada that sells products around the world that depends on that reputation" (McKie and Cribb 2008, p. 8).

These views were also expressed in the testimony of federal executives who appeared before the subcommittee. Morris Rosenberg, Deputy Minister of Health said: "Health Canada's role in the federal food partnership is to help build a strong foundation of food safety science. ... As a science-based organization we are continuously asking whether our policies and practices are keeping pace with the best science available" (House of Commons Committees, 22 April 2009, line 1830). Brian Evans, the Executive Vice President of the CFIA, told the subcommittee that: “... the HACCP application to food safety ... is the gold standard, as referenced by the United Nations groups on food safety, Codex Alimentarius, and the World Health Organization. It is advocated globally as the best standard or the best way" (House of Commons Committees, 20 April 2009, line 1925). James M. Laws, Canadian Meat Council, argued that [despite the outbreak] the Canadian food safety system was not broken. He said the ultimate responsibility was with industry as well as HACCP testing based on scientifically sound principles developed with government (House of Commons Committees, 13 May 2009). None waxed as eloquent, however, as Evans, who, in speaking of the complexity of food safety said: "To use a military metaphor ... the war against food safety risk is currently being prosecuted by an alliance of units, each with its own specialty and command structure. The enemy they face is dynamic and evolving. The terrain on which they fight is constantly shifting. That is a very challenging and complex environment. To expand on the metaphor further, what is required is a broad view of the campaign and an understanding of all the assets that can be brought to bear on the challenge before us. Vision and strategy are required at the highest levels, while strong, coordinated execution is required from all the supporting units" (House of Commons Committees, 8 June 2009, line 1915). Underscoring the importance of managing consent, Professor Sylvain Charlebois, of the University of Regina pointed out that: "Food safety is about consumer confidence, not just risks. Regulators and legislators are currently concerned only with safety and risk, not with perception.... we must protect the rapport between Canadian consumers and the food industry before it's too late" (House of Commons Committees, 4 May 2009, line 1800).
He also said, however, that in his study of global food safety systems, "Canada positioned well among industrialized countries, but more needs to be done" (House of Commons Committees, 4 May 2009, line 1790).

But these views were not unanimous. Amir Attaran, of the University of Ottawa and the Canadian Medical Association Journal, told of his involvement in a research project on the Listeria standard in 30 countries that included the US, the EU, and Brazil. He said that Canada's standard for Listeria monocytogenes ranks in 30th place when compared with those 30 countries (House of Commons Committees, 10 June 2009, line 1610). The spokesperson for the Ontario Independent Meat Processors (House of Commons Committees, 13 May 2009, line 1825), representing 600 smaller meat operations, said increased costs of meeting federal standards would have drastic effects on many of those she represented. Professor Charlebois pointed out (House of Commons Committees 4 May 2009), that the only federally licensed slaughtering plant in Saskatchewan closed because it was unable to meet the costs of federal regulations. Thomas Olson, representing the Bison Producers of Alberta, supported this with an example that "federal plants require things like paid parking lots while provincial plants don't" (House of Commons Committees, 1 June 2009, line 1650). These concerns were also shared by Conservative members, who resisted unilateral standards because of their impact of increased costs on smaller operations.

Nevertheless, the neoliberal emphasis was maintained because the focus returned, in the end, to federal authority over this particular case. The split was also evident in the Final Report of the Subcommittee on Food Safety (2009). There were, in fact two reports-a majority report supported by opposition MPs, who held a majority on the subcommittee, and a minority report prepared by the governing Conservative subcommittee members (only in Canada!). The majority report called for expansive neoliberalization of food safety extending beyond the system already organized around risk management, HACCP, and audit-based inspection. The minority report reaffirmed the present government's policies, did not reject neoliberalization, but at the same time, expressed support for some domestic and smaller-scale food operations reflecting, no doubt, the rural constituency base of some Conservative members.

Beyond the parliamentary hearings, there was further evidence of discrepancies from the neoliberal vision of food safety. With regard to food governance, the Independent Investigator pointed out that: (1) the enabling legislation (The Food and Drugs Act) was out of date and needed substantial consolidation; (2) the CFIA has never actually been authorized by Parliamentary vote despite several attempts since 1997 to achieve majority support; 
(3) the organization of the CFIA and the PHAC are conventionally bureaucratic and need greater flexibility. It was also pointed out that (4) the CFIA had failed to submit 5 -year business plans as required, (5) was lax in its consultation procedure with stakeholders, and (6) had substantial turnover in leadership. That is, despite a Presidential tenure of 5 years, no one has stayed a full term and there have been five Presidents in the past 12 years (Independent Investigator 2009, pp. 88-91). With regard to food sanitation, the CVS system had not been fully implemented and: (1) the CVS manual of procedures was out of date, (2) it was not practical to use, and (3) did not provide a clear way for inspectors to verify Listeria environmental controls in a plant. The Independent Investigator also concluded that (4) the CFIA had not provided adequate evaluation of new tasks and assessment of skills for inspection or (5) necessary resources to implement and staff the CVS, and (6) there was no longer a provision for environmental testing of food contact surfaces (Independent Investigator 2009, pp. 31-42). Finally, as described above, problems at the food production site included: (1) an explicit policy of "belt-tightening" which presumably affected sanitation practices, (2) gaps and lapses in sanitation procedures, (3) communication gaps in informing inspectors of positive findings of Listeria, (4) extensive demands on inspectors (due possibly to limitations in financing overtime inspection), and (5) failure to complete audits on schedule.

In sum, the science-based, neoliberalized approach to food safety was strongly supported by corporate and bureaucratic executives. This enthusiasm was not fully shared by a number of others in the food production net, however, including Conservative members of the parliamentary subcommittee. Nevertheless, even these objections and deficiencies were framed within the neoliberalized agenda of food safety. Food safety served, then, as an attractor, organizing consent for an inspection system that was under-financed, under-developed, and based on audits of written records, in appraising a situation rife with opportunistic corporate practices.

\section{Conclusion}

This paper has examined material regarding the 2008 listeriosis outbreak at a Maple Leaf Foods plant that resulted in twenty-three deaths. It focused on two aspects of the social relations that were involved. The first involved showing how activities and practices in the organization of food production, sanitation, and governance were linked with the outbreak. In food production, a corporate climate of belt-tightening, faulty safety practices, and inadequate inspection practices provided a setting into which a rapid increase of production occurred. The machines were slicing greater quantities of a product that was more vulnerable to Listeria, which led to reduced time for sanitation and inspection. With regard to food sanitation, the recently remodeled, under-resourced, and under-utilized inspection system did not detect the problem, so contamination was the result. The organization of food governance was shown to be a conglomerate of jurisdictional ventures and in some cases, disconnected from the legal and political authority expected in a neoliberalized federal arrangement.

These practices were also examined in terms of their relation to the food production network. They revolved around a neoliberalized version of food safety as a nationally integrated and science-based set of risk management strategies that are harmonized with international trade standards. Food safety served as an attractor, providing the agenda with reference to which actors and organizational relations were mobilized. It was clear that the neoliberal formulation was not completely accepted nor was it sufficient to prevent the contamination; yet, even the disagreement and discrepancies were framed within the discursive agenda it set. Despite the commitment to neoliberalism and the implementation of a neoliberal project with its attendant strategy, the material relating to the listeriosis outbreak provides evidence of a process of neoliberalization that is certainly less than complete. Through the neoliberal lens, Canadian food safety is portrayed by the heroic vision of a science-based, streamlined, efficient system of production and inspection. In actuality, it appears to be more of a cybercratic layer of rhetoric and programs that, not unlike a Listerian biofilm, is intended to saturate and colonize a diverse political and agri-industrialized food network.

Acknowledgments The authors would like to acknowledge the valuable comments of the editor and four anonymous reviewers. They helped improve it substantially and their positive comments encouraged us in the task.

\section{References}

Anonymous. 2007. Food safety enhancement program manual, ed. Canadian Food Inspection Agency. Government of Canada.

Anonymous. 2008. Machines "smelled like hell." Timmins, Ontario: Timmins Daily Press. 6 Aug 2008. http://www.timminspress. com/PrintArticle.aspx?e=1179856. Accessed 6 Sept 2008.

Bortolussi, R. 2008. Listeriosis: A primer. Canadian Medical Association Journal 179: 795-797.

Buckley, W. 1967. Sociology and modern systems theory. Englewood Cliffs: Prentice-Hall.

Busch, L. 2004. Grades and standards in the social construction of safe food. In Politics of food, ed. M.E. Lien, and B. Nerlich, 163-178. Oxford: Berg.

Busch, L. 2001. The homiletics of risk. Journal of Agricultural and Environmental Ethics 15: 17-29.

Canadian Press. 2008. Meat inspection system working properly: Ritz. Globe and Mail. 27 Aug 2008. http://www.theglobeandmail. 
com/servlet/story/RTGAM.20080827.wmlritz0827/BNStory/ National/. Accessed 27 Sep 2008.

Carroll, W.K. 1990. Restructuring capital, reorganizing consent: Gramsci, political economy, and Canada. Canadian Review of Sociology and Anthropology 27: 390-416.

Chase, S., K. Howlett, and G. Keenan. 2008. Harper vows to launch tainted-meat inquiry. Globe and Mail. 3 September 2008. http:// www.theglobeandmail.com/servlet/story/RTGAM.20080903. welect_harper04/BNStory/National/home. Accessed 4 September 2008 .

Chief Medical Officer of Health. 2009. Chief Medical Officer of Health's Report on the Management of the 2008 Listeriosis Outbreak in Ontario. Queen's Printer for Ontario.

CFIA (Canadian Food Inspection Agency). 2009a. Lessons learned: The Canadian Food Inspection Agency's recall response to the 2008 listeriosis outbreak. Government of Canada.

CFIA (Canadian Food Inspection Agency). 2009b. Lessons learned: The Canadian Food Inspection Agency's review of Est. 97B (Maple Leaf Consumer Foods Inc.). Government of Canada.

CFIA (Canadian Food Inspection Agency). 2009c. Inspection reports and establishment grades for the federally licensed Maple Leaf Plant on Bartor road in Toronto and verification worksheets for Est. 97b, 1-182. Government of Canada.

Coe, N.M., M. Hess, W.H. Yeung, P. Dicken, and J. Henderson. 2004. "Globalizing" regional development: A global production networks perspective. Transactions of the Institute of British Geographers 29: 468-484.

Cribb, R. 2008a. Listeria found in nursing homes, hospitals. Toronto Star. 9 Oct 2008. http://www.healthzone.ca/health/articlePrint/ 514527. Accessed 13 Oct 2008.

Cribb, R. 2008b. Emails a window on listeria outbreak: Candid missives sent by Maple Leaf boss show company slow to recognize threat. Toronto Star. 24 Nov 2008. http://www. thestar.com/comment/columnists/article/533057. Accessed 24 Nov 2008.

Dell'Era, S., C. Buchrieseer, E. Couvé, B. Schnell, Y. Briers, M. Schuppler, and M.J. Loessner. 2009. Listeria monocytogenes L-forms respond to cell wall deficiency by modifying gene expression and the mode of division. Molecular Microbiology 73: 306-322.

Farber, J.M., F. Pagotto, and C. Scherf. 2007. Incidence and Behavior of Listeria monocytogenes in Meat Products. In Listeria, listeriosis and food safety, ed. E.T. Reyser, and E.H. Marth, 503-570. Boca Raton: CRC Publishers.

Galbraith, J.K. 1952. American capitalism. Hammondsworth: Penguin.

Gereffi, G., J. Humphrey, and T. Sturgeon. 2005. The governance of global value chains. Review of International Political Economy 12: $78-104$.

Gereffi, G., and M. Korzeniewicz. 1994. Commodity chains and global capitalism. Westport: Praeger.

Gibbon, P., J. Bair, and S. Ponte. 2008. Governing global value chains: An introduction. Economy and Society 37: 315-338.

Globe and Mail. 2008. Editorial: Question of timing. 26 Aug 2008. http://v1.theglobeandmail.com/servlet/story/RTGAM.20080826. wemeat26/REStory/RealEstate/. Accessed 26 Aug 2008.

Gramsci, A. 1971. Selections from prison notebooks. London: Lawrence and Wishart.

Guthman, J. 2008. Neoliberalism and the making of food politics in California. Geoforum 39: 1171-1183.

Guthman, J. 2007. The Polanyian way? Voluntary food labels as neoliberal governance. Antipode 39: 456-478.

Guthman, J. 2006. Embodying neoliberalism: Economy, culture, and the politics of fat. Environment and Planning D: Society and Space 24: 427-448.
Harvey, D. 2005. A brief history of neoliberalism. Oxford: Oxford University Press.

Hatanaka, M., and L. Busch. 2008. Third-party certification in the global agrifood system: An objective or socially mediated governance mechanism? Sociologia Ruralis 48: 73-91.

Health Canada. 2009. Lessons learned report: Health Canada's response to the 2008 listeriosis outbreak. Government of Canada.

Heim, S., M. Del Mar Lleo, B. Bonato, C.A. Guzman, and P. Canepari. 2002. The viable but nonculturable state and starvation are different stress responses of Enterococcus faecalis, as determined by proteome analysis. Journal of Bacteriology 184: 6739-6745.

Hess, M. 2008. Governance, value chains, and networks: An afterword. Economy and Society 37: 452-459.

House of Commons Committees. 2009. Subcommittee on food safety of the standing committee on agriculture and agri-food: Evidence (SFSA). House of Commons Committees. 40th Parliament, Second Session. Government of Canada.

Howlett, K., and C. Alphonso. 2008. Agency waited 5 days to issue recall. Globe and Mail. Toronto, Ontario.

Hudson, R. 2004. Conceptualizing economies and their geographies: Space, flows, and circuits. Progress in Human Geography 28: 447-471.

Hymer, S. 1971. Partners in development: The multinational corporation and its allies. Newstatement 1: 4-15.

Independent Investigator. 2009. Report of the independent investigator into the 2008 Listeriosis outbreak. Government of Canada.

Jessop, B. 2002. Liberalism, neoliberalism, and urban governance: A state-theoretical perspective. Antipode 34: 452-472.

Juska, A., L. Gouveia, J. Gabriel, and K.P. Stanley. 2003. Manufacturing bacteriological contamination outbreaks in industrialized meat production systems: The case of E. coli O157:H7. Agriculture and Human Values 20: 3-19.

Lado, B.H., and A.E. Yousef. 2007. Characteristics of Listeria monocytogenes important to food processors. In Listeria, listeriosis, and food safety, ed. E.T. Reyser, and E.H. Marth, 157-213. Boca Raton: CRC Publishers.

Laxer, G. 1995. Social solidarity, democracy, and global capitalism. The Canadian Review of Sociology and Anthropology 32: 287-313.

McKie, D., and R. Cribb. 2008. Interview with Maple Leaf president Michael McCain. Canadian Broadcasting Corporation. 8 Nov 2008. http://www.cbc.ca/canada/story/2008/11/07/transcriptlisteria.html. Accessed 22 Nov 2008.

Millstone, E. 2007. Can food safety policy-making be both scientifically and democratically legitimated? If so, how? Journal of Agricultural and Environmental Ethics 20: 483-508.

Millstone, E., E. Brunner, and S. Mayer. 1999. Beyond "substantial equivalence". Nature 401: 525-526.

Mutersbaugh, T. 2005. Just-in-space: Certified rural products, labor of quality, and regulatory spaces. Journal of Rural Studies 21: 389-402.

Orton, J.D., and K.E. Weick. 1990. Loosely coupled systems: A reconceptualization. The Academy of Management Review 15: 203-223.

Pechlaner, G., and G. Otero. 2010. The neoliberal food regime: Neoregulation and the new division of labor in North America. Rural Sociology 75: 179-208.

Peck, J., and A. Tickell. 2002. Neoliberalizing space. Antipode 34: 380-404.

PHAC (Public Health Agency of Canada). 2009. Lessons learned: Public Health Agency of Canada's response to the 2008 listeriosis outbreak. Government of Canada.

Polanyi, K. 1944. The great transformation. Boston: Beacon Press.

Post, D.L. 2005. Standards and regulatory capitalism: The diffusion of food safety standards in developing countries. The ANNALS of 
the American Academy of Political and Social Science 598: $168-188$.

Pritchard, B., and R. Fagan. 1999. Circuits of capital and transnational corporate spatial behavior: Nestlé in Southeast Asia. International Journal of Sociology of Agriculture and Food 8: 3-20.

Sardessai, Y.N. 2005. Viable but non-culturable bacteria: Their impact on public health. Current Science 89: 1650.

Schmidt, S. 2009. Overhaul for food safety in Canada. Victoria Times-Colonist. 13 Nov 2009. http://www.fpinfomart.ca/news/ ar_results.php?q=2472893\&sort=pubd\&page $=1 \& n[\mathrm{db}][]=$ vitc. Accessed 13 Nov 2009.

Schmidt, S. 2008. Meat inspectors face fatigue. National Post. 27 Aug 2008. http://www.nationalpost.com/opinion/columnists/Meat+ inspectors+face+fatigue/750905/story.html. Accessed 29 Aug 2008.

Stewart, C.M., R. Bruce Tompkin, and M.B. Cole. 2002. Food safety: New concepts for the new millennium. Innovative Food Science and Emerging Technologies 3: 105-112.

Subcommitte on Food Safety. 2009. Beyond the listeriosis crisis: Strengthening the food safety system. Government of Canada.

Szabo, E.A., W.R. Porter, and C.L. Sahlin. 2008. Outcome based regulations and innovative food processes: An Australian perspective. Innovative Food Science and Emerging Technologies 9: 249-254.

Talbot, J.M. 2002. Tropical commodity chains, forward integration strategies, and international inequality: Coffee, cocoa, and tea. Review of International Political Economy 9: 731-734.

Treasury Board. 2001. Integrated risk management framework. Government of Canada.

\section{Author Biographies}

Ken Hatt Ph.D. is an Adjunct Professor in the Department of Sociology at the University of Victoria in Victoria, BC, Canada, and on the graduate faculty at the Open University of Catalonia (UOC), Spain, where he teaches a graduate course in Trade Liberalization and Food Governance. His research has focused on studies of resistance and reform in and around Canadian state hegemony through three waves of capitalism: the Canadian Métis following the fur trade; liberal and neoliberal reconstruction in Canadian criminal justice; and, most recently, local, organic, traditional, and urban small farming in an era of global trade liberalization.

Kierstin Hatt Ph.D. is Associate Professor of Sociology at Augustana Campus of the University of Alberta. Her interests include gender, global and development studies, and socio-environmental sustainability. She has been involved in research relating to politicaleconomic, socio-cultural, and environmental aspects of food systems, in particular the Costa Rican banana industry. She was co-editor, with Debra Davidson, of Consuming sustainability: Critical social analyses of ecological change. Recently, she has also been involved in participatory action research relating to dietary and other forms of intervention for autism spectrum disorders. 